\title{
EFFECTS OF VITAMIN E AND VITAMIN C ON MERCURY INDUCED TOXICITY IN MICE
}

\author{
M. A. Huq, M. A. Awal, M. Mostofa, A. Ghosh and A. R. Das \\ Department of Pharmacology, Bangladesh Agricultural University \\ Mymensingh-2202, Bangladesh
}

\begin{abstract}
The present study was undertaken to find out the efficacy of vitamin E and/or vitamin $\mathrm{C}$ against mercury $(\mathrm{Hg})$ induced toxicity in mice. Sixty mice were randomly divided into 5 equal groups $(n=12)$. One group of mice (Group A) was kept as control and each of rest four groups (B, C, D and E) were fed with mercuric chloride $\left(\mathrm{HgCl}_{2}\right)$ in drinking water @ $65 \mathrm{mg} / \mathrm{L}$. In addition to $\mathrm{HgCl}_{2}$ alpha-tocopherol (vitamin E) @ 100 mg/L, ascorbic acid (vitamin C) @ $250 \mathrm{mg} / \mathrm{L}$ and combination of vitamin $\mathrm{E}$ and vitamin $\mathrm{C}$ at same dose were given to the mice of groups C, D and E respectively. All treatments were continued for 28 consecutive days. Four mice of each group were sacrificed on day 1, 14 and 28 and efficacy of vitamin $\mathrm{E}$ and vitamin $\mathrm{C}$ against $\mathrm{Hg}$ induced toxicity were evaluated by observing toxic signs, body weight, hemato-biochemical parameters and postmortem lesions. Mild (++) toxic signs as evident by reduced feed and water intake, salivation, vomiting, excitement, muscle tremor, ataxia, restlessness, incordination and ruffled hair coat were observed from $2^{\text {nd }}$ week (group B) and from $3^{\text {rd }}$ week (group $\mathrm{C}$ and D) by intoxication with $\mathrm{HgCl}_{2}$. Significant $(\mathrm{P}<0.01)$ reduction of body weight $(18.38 \%)$ and hematological parameters i.e. TEC (19.88\%), TLC $(27.89 \%), \mathrm{Hb}$ content $(34.09 \%)$ and PCV (9.15\%) were observed at day 28 in $\mathrm{HgCl}_{2}$ induced intoxicated mice (group B). At identical period in same group biochemical parameters i.e. AST $(46.99 \%)$ and ALT $(58.72 \%)$ increased significantly $(p<0.01)$. Pinpoint hemorrhages throughout the liver and highly $(++++)$ congested kidney was also observed at post mortem (group B). All the parameters i.e. toxic signs, body weight, hemato-biochemical and post mortem lesions were found to be slight $(+)$ or mild $(++)$ and/or improved in rest three groups of mice following treatment with vitamin $\mathrm{E}$, vitamin $C$ and combination of vitamin $E$ and vitamin $C$. The present study reveals that vitamin $\mathrm{E}$ and $\mathrm{C}$ have a protective role against $\mathrm{Hg}$ poisoning. However, combination of vitamin $\mathrm{E}$ and $\mathrm{C}$ gave better results.
\end{abstract}

Key words : Mercury, Alpha-tocopherol, Ascorbic acid

\section{INTRODUCTION}

Mercury $(\mathrm{Hg})$ is widely considered as one of the most toxic substances on earth (Clarkson, 1997). It is one of five elements that are liquid at or near room temperature and pressure. It is used in thermometers, barometers and other scientific apparatus, although its use in thermometers has been largely phased out in clinical environments due to 
concerns about the element's toxicity. $\mathrm{Hg}$ poisoning is an emerging problem in Bangladesh due to increasing tendency of its industrial exploitation. Once $\mathrm{Hg}$ is released into the environment it can be changed to methyl mercury, a highly toxic compound, which is easily taken up in living tissue and bioaccumualate over time, causing serious health effects in human and wild life (Uchino et al., 1995). It also altered the hematological and biochemical parameters (Arvind et al., 1993; Bersenyi et al., 2003) in animal model.

$\mathrm{Hg}$ exerts its effect by the inhibition of glutathione peroxidase activity (Hirota, 1986). Its toxic effect may be combated by chelating agents like BAL (2, 3 dimercaptopropanol), DMSA (2, 3 dimercaptosuccinic acid) (Houeto et al., 1994) and antioxidants but use of chelating agents in metal poisons is beyond satisfaction. The potential of dietary antioxidants against metal poison has drawn increasing attention in recent years. As vitamin $\mathrm{E}$ and vitamin $\mathrm{C}$ have antioxidant property therefore it can be speculated that these could have a protective role in $\mathrm{Hg}$ induced toxicity through scavenging free radicals. By considering these facts this study was undertaken to investigate the combating effects of vitamin $\mathrm{E}$ and vitamin $\mathrm{C}$ against $\mathrm{Hg}$ induced toxicity in mice.

\section{MATERIALS AND METHODS}

\section{Chemicals and drugs}

All chemicals used were of the highest grade commercially available. Purified mercuric chloride $\left(\mathrm{HgCl}_{2}\right)$ and sodium citrate was collected from E-Merck, Darmsteadt, Germany. Giemsa's stain powder was purchased from The British Drug House, England. Alphatocopherol (E Vet ${ }^{\circledR}$ powder, $100 \mathrm{~g}$ contains alpha-tocopherol acetate BP $10 \mathrm{~g}$ ) from The Acme Laboratories Ltd., Dhaka, Bangladesh and ascorbic acid (Ceevit ${ }^{\circledR}$ Tablet, each tablet contains $250 \mathrm{mg}$ ) from Square Pharmaceutical Ltd., Bangladesh.

\section{Mice selection and care}

Sixty Swiss Albino male mice (30 days old), weighing between 45-55 g and collected from the Department of Microbiology and Hygiene, Bangladesh Agricultural University (BAU), Mymensingh were used in this experiment. All animals were housed in compartmented rectangular metallic cage wrapped with wire mesh in the laboratory, Department of Pharmacology, BAU, Mymensingh under standard laboratory conditions (14 h light : $10 \mathrm{~h}$ dark, $30 \pm 2{ }^{\circ} \mathrm{C}$ and humidity $60 \pm 5 \%$ ) with free access to food and deionized water for drinking. The animals were kept 2 weeks without treatment for acclimatization. The experimental protocol was duly approved by the Animal Ethics Committee of the Department.

\section{Grouping and drug treatment}

Mice were randomly divided into 5 equal groups (A-E) consisting of 12 mice in a group and their initial body weight was noted. One group of mice (group A) was kept as control. All animals (group B, C, D and E) except control (group A) received $\mathrm{HgCl}_{2} @ 65$ 
$\mathrm{mg} / \mathrm{L}$ in drinking water. In addition to $\mathrm{HgCl}_{2}$ alpha-tocopherol @ $100 \mathrm{mg} / \mathrm{L}$ and ascorbic acid @ $250 \mathrm{mg} / \mathrm{L}$ were given to mice of $\mathrm{C}$ and $\mathrm{D}$ groups, respectively. In group $\mathrm{E}$ combination of both vitamins as same dose were given with $\mathrm{HgCl}_{2}$. All treatments were continued for 28 consecutive days.

\section{Animal sacrifice and collection of blood}

Four mice of each group were sacrificed on day 1, 14 and 28 just after treatment between 9-10 a.m. euthanized by ether anesthesia. Before sacrifice body weights of the animals were noted. The abdomen of each mouse was opened by midline incision. Blood samples were collected directly by cardiac puncture using disposable syringe (30 gauze needles) after opening the abdomen. Immediately after collection, one part was transferred to sterile tube containing anticoagulant (4\% sodium citrate) at a ratio of 1:10 for hematological parameters. Serum samples were separated from the other part by centrifugation at $3000 \mathrm{rpm}$ and stored at $-20^{\circ} \mathrm{C}$ until use for biochemical parameters.

\section{Recording of clinical parameters}

Clinical signs like anorexia, salivation, vomiting, muscle tremor, excitement, restlessness, ataxia, incordination, ruffled hair coat and anuria were closely observed during the experiment. After sacrifice gross pathological lesions of liver, heart, kidney, spleen and lung were recorded. Severity of clinical signs and postmortem lesions were noted as slight $(+)$, mild $(++)$, moderate $(+++)$ and high $(++++)$.

\section{Hematological and biochemical parameters}

Hematological parameters like Total Erythrocyte Count (TEC), Total Leukocyte Count (TLC), Hemoglobin ( $\mathrm{Hb}$ ) Content and Packed Cell Volume (PCV) were determined as per method cited by Coffin (1955). Biochemical parameters like aspartate aminotransferase (AST) and alanine aminotransferase (ALT) were measured using Reflotron ${ }^{(R)}$ plus, Roche Diagnostics GbH, D-68298 Mannheim, Germany at $37^{\circ} \mathrm{C}$.

\section{Statistical analyses}

Data obtained on body weight, hematological and biochemical parameters were analyzed using students paired T-test following the standard methods (Khan, 1989) and expressed as mean \pm S.E.

\section{RESULTS AND DISCUSSION}

\section{Effect on body weight}

The effect of alpha-tocopherol (vitamin E) and ascorbic acid (vitamin C) against $\mathrm{HgCl}_{2}$ intoxication on body weight gain in mice are presented in Table 1. Significant $(\mathrm{p}<0.01)$ gradual increase of body weight $(18.38 \%)$ was found in control group at the end of the experiment but during same period in all the treated groups the body weight was found to decrease significantly $(\mathrm{p}<0.01)$. 
Table 1. Effect of mercuric chloride alone and in combination with vitamin $\mathrm{E}$ and $\mathrm{C}$ supplementation on mean body weight (g) in mice

\begin{tabular}{l|c|c|c}
\hline \multirow{2}{*}{ Treatment in groups } & \multicolumn{3}{|c}{ Body weight $(\mathrm{g})$} \\
\cline { 2 - 4 } & Day-1 & Day-14 & Day-28 \\
\hline Control (A) & $50.55 \pm 0.43$ & $55.70 \pm 0.33$ & $59.79 \pm 0.08$ \\
& & $\left(10.19 \%^{\mathrm{a}}\right)$ & $\left(18.38 \%^{\mathrm{a}}\right)$ \\
Mercuric chloride (B) & $49.63 \pm 0.29$ & $46.25 \pm 0.42^{* *}$ & $42.44 \pm 0.21^{* *}$ \\
& & $\left(6.81 \%^{\mathrm{b}}\right)$ & $\left(14.49 \%^{\mathrm{b}}\right)$ \\
Mercuric chloride + Alpha- & $50.72 \pm 0.18$ & $49.12 \pm 0.06$ & $47.12 \pm 0.06^{* *}$ \\
tocopherol (C) & & $\left(3.15 \%^{\mathrm{b}}\right)$ & $\left(7.10 \%^{\mathrm{b}}\right)$ \\
Mercuric chloride + Vit C (D) & $49.71 \pm 0.18$ & $47.75 \pm 0.13$ & $45.14 \pm 0.14^{* *}$ \\
& & $\left(3.94 \%^{\mathrm{b}}\right)$ & $\left(9.19 \%^{\mathrm{b}}\right)$ \\
Mercuric chloride + Alpha- & $50.74 \pm 0.30$ & $49.58 \pm 0.27$ & $47.43 \pm 0.18^{* *}$ \\
tocopherol + Vit C (E) & & $\left(2.29 \%^{\mathrm{b}}\right)$ & $\left(7.08 \%^{\mathrm{b}}\right)$ \\
\hline
\end{tabular}

Values above represent the mean \pm SE of 4 mice; ${ }^{*}$ Significantly decreased $(\mathrm{p}<0.01) ;(\% \mathrm{a})$ percent increased; $(\%$ b $)$ percent decreased

Highest reduction $\left(14.49 \%\right.$ ) of body weight was observed with $\mathrm{Hgcl}_{2}$ intoxication (group B). The reduction was less $(7.08 \%)$ in combined treated group (group E) compared to group C $(7.10 \%)$ and group D $(9.19 \%)$ treated with vitamin $\mathrm{E}$ and vitamin $\mathrm{C}$ alone.

Reduction of body weight under the influence of $\mathrm{Hg}$ in all groups indicated that $\mathrm{Hg}$ has a detrimental effect on growth. Similarly several other researchers also reported loss of body weight in experimental animals following $\mathrm{Hg}$ intoxication (Naganuma et al., 1984; Chowdhury et al., 1986). Minor improvement of body weight in both vitamin E and C treated groups indicated that vitamin $\mathrm{E}$ and $\mathrm{C}$ could partially defend the $\mathrm{HgCl}_{2}$ intoxication and the results accorded with the previous findings (Hossain, 2005). Use of vitamin $\mathrm{E}$ and $\mathrm{C}$ against $\mathrm{Hg}$ intoxication was found better than their individual treatment as both antioxidants worked synergistically as evident in this study.

\section{Toxic signs and post mortem lesions}

Mild (++) toxic sign was observed in $\mathrm{HgCL}_{2}$ intoxicated group (Group B) from $2^{\text {nd }}$ week of treatment showing reduced feed and water intake, salivation, vomiting, excitement, muscle tremor, ataxia, restlessness, incordination, ruffled hair coat and anuria. This was aggravated in course of time. Mild (++) toxic signs from the $3^{\text {rd }}$ week as evident by anorexia, salivation, excitement, restlessness, ruffled hair coat were also observed in group $C$ and $D$. In group $E$, slight $(+)$ toxic signs were observed from $3^{\text {rd }}$ week of treatment which was milder compared to group B, C and D. All the rats of control group (Group A) were normal throughout the experiment period.

In post mortem examination at day 14, slight $(+)$ congestion and hemorrhage in kidney and liver were found in $\mathrm{HgCl}_{2}$ intoxicated group (group B). Treatment with vitamin $\mathrm{E}$ and $\mathrm{C}$ alone and in combination did not show any lesions at identical time. At day 28, 
these lesions aggravated in group B as manifested by highly $(++++)$ congested kidney, pinpoint hemorrhages throughout the liver and mild $(++)$ hemorrhages throughout the stomach, heart, lung and testes. Slight $(+)$ hemorrhages and congestion were found in lung, kidney, liver and testes at day 28 in vitamin $\mathrm{E}$ and $\mathrm{C}$ treated groups. Lesions $(+)$ were also found in combined treated group but in milder form.

Hg has detrimental effect on physiological function as manifested by toxic symptoms and alteration of hematological and biochemical parameters. Previous reports indicated that acute ingestion of $\mathrm{Hg}$ salts may cause gastrointestinal disorders (ATSDR, 1989). Repeated and prolonged exposure has resulted in a reduction of sensory and motor nerve function, depression, visual and auditory hallucinations, muscular tremors, sleep disorders, alterations in autonomic function, impaired vasomotor coordination, speech disorders, dementia, coma and death (Goyer, 1991; Ngim et al., 1992). In accordance with the present findings, similar types of toxic symptoms were also observed by $\mathrm{Hg}$ vapor intoxication in man (Houeto et al., 1994) and animals (Carratu et al., 2006).

\section{Hematological and biochemical parameters}

The effects of $\mathrm{HgCl}_{2}$ alone and in combination with vitamin $\mathrm{E}$ and $\mathrm{C}$ on hematological values in mice are presented in Table 2 and Table 3.

Table 2. Effect of mercuric chloride alone and in combination with vitamin $\mathrm{E}$ and $\mathrm{C}$ supplementation on TEC (million/cu.mm) and TLC (thousand/cu.mm) in mice

\begin{tabular}{|c|c|c|c|c|c|c|}
\hline \multirow[t]{2}{*}{ Treatment in groups } & \multicolumn{3}{|c|}{ TEC ( million/cu mm) } & \multicolumn{3}{|c|}{ TLC (thousand/cu.mm) } \\
\hline & Day-1 & Day-14 & Day-28 & Day-1 & Day-14 & Day-28 \\
\hline Cont & $8.55 \pm 0.24$ & $\begin{array}{l}8.85 \pm 0.06 \\
(3.51 \% a)\end{array}$ & $\begin{array}{c}8.93 \pm 0.07 \\
(4.4 \% \mathrm{a})\end{array}$ & $9.20 \pm 0.04$ & $\begin{array}{c}9.45 \pm 0.06 \\
(2.7 \% \mathrm{a})\end{array}$ & $\begin{array}{l}9.53 \pm 0.17 \\
(3 . .53 \% \mathrm{a})\end{array}$ \\
\hline Mercuric chloride (B) & $8.4 \pm 0.25$ & $\begin{array}{c}7.23 \pm 0.27^{* *} \\
(13.93 \% \mathrm{~b})\end{array}$ & $\begin{array}{c}6.73 \pm 0.06^{* *} \\
(19.88 \% \mathrm{~b})\end{array}$ & $9.28 \pm 0.13$ & $\begin{array}{c}7.81 \pm 0.15^{\star *} \\
(15.80 \% \mathrm{~b})\end{array}$ & $\begin{array}{l}6.69 \pm 0.29^{* *} \\
(27.89 \% \mathrm{~b})\end{array}$ \\
\hline $\begin{array}{l}\text { Mercuric chloride + } \\
\text { Alpha-tocopherol (C) }\end{array}$ & $8.80 \pm 0.13$ & $\begin{array}{l}8.0 \pm 0.17 \\
(9.09 \% \mathrm{~b})\end{array}$ & $\begin{array}{c}7.89 \pm 0.05^{\star *} \\
(10.34 \% \mathrm{~b})\end{array}$ & $9.28 \pm 0.13$ & $\begin{array}{l}8.45 \pm 0.06 \\
(8.94 \% \text { b) }\end{array}$ & $\begin{array}{l}8.19 \pm 0.12^{* *} \\
(11.77 \% \text { b })\end{array}$ \\
\hline $\begin{array}{l}\text { Mercuric chloride + } \\
\text { Vit C (D) }\end{array}$ & $8.79 \pm 0.08$ & $\begin{array}{c}7.83 \pm 0.05^{* *} \\
(10.92 \% \mathrm{~b})\end{array}$ & $\begin{array}{c}7.46 \pm 0.07^{* *} \\
(15.13 \% \mathrm{~b})\end{array}$ & $9.84 \pm 0.07$ & $\begin{array}{c}9.11 \pm .09^{* *} \\
(7.40 \% \mathrm{~b})\end{array}$ & $\begin{array}{l}8.61 \pm 0.37^{* *} \\
(12.45 \% \mathrm{~m})\end{array}$ \\
\hline $\begin{array}{l}\text { Mercuric chloride + } \\
\text { Alpha-tocopherol + } \\
\text { Vit C (E) }\end{array}$ & $\begin{array}{c}8.71 \pm 0.11 \\
(3.51 \% \mathrm{a})\end{array}$ & $\begin{array}{l}8.08 \pm 0.11 \\
(7.23 \% \mathrm{~b})\end{array}$ & $\begin{array}{c}8.00 \pm 0.11^{* *} \\
(8.15 \% \mathrm{~b})\end{array}$ & $9.65 \pm 0.13$ & $\begin{array}{l}9.06 \pm 0.04 \\
\left(6.17 \%^{b}\right)\end{array}$ & $\begin{array}{c}8.74 \pm 0.13^{* *} \\
(9.48 \% \text { b })\end{array}$ \\
\hline
\end{tabular}

Values above represent the mean $\pm \mathrm{SE}$ of 4 mice; ${ }^{* *}$ Significantly decreased $(\mathrm{p}<0.01) ;\left(\%^{\mathrm{a}}\right)$ percent increased; $(\%$ b $)$ percent decreased

Significant $(\mathrm{p}<0.01)$ reduction of TEC $(19.88 \%)$, TLC $(27.89 \%), \mathrm{Hb}(34.09 \%)$ content and PCV $(9.15 \%)$ were recorded in $\mathrm{HgCl}_{2}$ intoxicated mice (group B) at day 28 of treatment. Use of vitamin $\mathrm{E}$ in inebriated mice for the same period somewhat regained the values as 
evident by less reduction of TEC (10.34\%), TLC (11.77\%), Hb (15.67\%) content and PCV $(5.28 \%)$. On the contrary, vitamin $\mathrm{C}$ also improved the condition as manifest by reduction of TEC, TLC, $\mathrm{Hb}$ content and PCV were of $15.13 \%, 12.45 \%, 16.15 \%$ and $7.23 \%$, respectively on day 28 of treatment. Combined treatment with the same vitamins at equal dose and duration showed better than alone (reduction of TEC, TLC, Hb content and PCV were of $8.15 \%, 9.48 \%, 10.79 \%$ and $3.09 \%$ respectively) but none of the therapy failed to regain the blood pictures to control level.

Table 3. Effects of mercuric chloride alone and in combination with vitamin $\mathrm{E}$ and $\mathrm{C}$ supplementation on hemoglobin content $(\mathrm{g} \%)$ and PCV in mice

\begin{tabular}{|c|c|c|c|c|c|c|}
\hline \multirow[t]{2}{*}{ Treatment in groups } & \multicolumn{3}{|c|}{ Hemoglobin content (g \%) } & \multicolumn{3}{|c|}{ PCV } \\
\hline & Day-1 & Day-14 & Day-28 & Day-1 & Day-14 & Day-28 \\
\hline Control (A) & $9.70 \pm 0.11$ & $\begin{array}{c}10.10 \pm 0.09 \\
\left(4.10 \%{ }^{a}\right)\end{array}$ & $\begin{array}{c}10.43 \pm 0.05 \\
\left(7.50 \%{ }^{a}\right)\end{array}$ & $\begin{array}{c}41.73 \pm \\
0.55\end{array}$ & $\begin{array}{c}42.15 \pm 0.44 \\
(1.01 \%)\end{array}$ & $\begin{array}{c}42.36 \pm 0.34 \\
(1.51 \% \mathrm{a})\end{array}$ \\
\hline Mercuric chloride (B) & $9.62 \pm 0.05$ & $\begin{array}{c}8.15 \pm 0.07^{* *} \\
(15.21 \% \mathrm{~b})\end{array}$ & $\begin{array}{c}6.34 \pm 0.16^{* *} \\
(34.09 \% \mathrm{~b})\end{array}$ & $\begin{array}{c}41.03 \pm \\
0.11\end{array}$ & $\begin{array}{c}39.20 \pm 0.10 \\
4.46 \%\end{array}$ & $\begin{array}{c}37.27 \pm 0.05^{* *} \\
(9.15 \% \mathrm{~b})\end{array}$ \\
\hline $\begin{array}{l}\text { Mercuric chloride + } \\
\text { Alpha-tocopherol (C) }\end{array}$ & $9.58 \pm 0.06$ & $\begin{array}{l}9.11 \pm 0.16 \\
\left(4.83 \%{ }^{b}\right)\end{array}$ & $\begin{array}{c}8.08 \pm 0.09^{* *} \\
(15.67 \% \mathrm{~b})\end{array}$ & $\begin{array}{c}40.35 \pm \\
0.11\end{array}$ & $\begin{array}{c}39.10 \pm 0.10 \\
(3.10 \%)\end{array}$ & $\begin{array}{c}38.22 \pm 0.05^{* *} \\
(5.28 \% \mathrm{~b})\end{array}$ \\
\hline $\begin{array}{l}\text { Mercuric chloride + } \\
\text { Vit C (D) }\end{array}$ & $9.60 \pm 0.07$ & $\begin{array}{c}9.06 \pm 0.36^{* *} \\
(5.60 \% \mathrm{~b})\end{array}$ & $\begin{array}{c}8.05 \pm 0.08^{* *} \\
(16.15 \% \mathrm{~b})\end{array}$ & $\begin{array}{c}40.53 \pm \\
0.38\end{array}$ & $\begin{array}{c}38.40 \pm 0.28 \\
(5.25 \%)\end{array}$ & $\begin{array}{c}37.60 \pm 0.40^{* *} \\
\left(7.23 \%{ }^{b}\right)\end{array}$ \\
\hline $\begin{array}{l}\text { Mercuric chloride + } \\
\text { Alpha-tocopherol + } \\
\text { Vit C (E) }\end{array}$ & $9.53 \pm 0.08$ & $\begin{array}{c}9 . .11 \pm 0.08 \\
\left(4.33 \% \mathrm{w}^{\mathrm{b}}\right)\end{array}$ & $\begin{array}{c}8.50 \pm 0.10^{* *} \\
(10.79 \% \mathrm{~b})\end{array}$ & $\begin{array}{c}40.56 \pm \\
0.36\end{array}$ & $\begin{array}{c}40.00 \pm 0.26 \\
(1.38 \%)\end{array}$ & $\begin{array}{c}39.31 \pm 0.53 \\
(3.09 \% \text { b }\end{array}$ \\
\hline
\end{tabular}

Values above represent the mean \pm SE of 4 mice; ${ }^{*}$ Significantly decreased $(\mathrm{p}<0.01) ;(\% \mathrm{a})$ percent increased; $\left(\%^{b}\right)$ percent decreased

Reduction of hematological values in $\mathrm{Hg}$ induced intoxication might be due to the untoward effects of mercuric chloride on the haemopoietic organs of the body. Exact mechanism of these reductions could not be fully explained because of lack of research in this field. However, the present findings are in accordance to the previous reports (Kling and Soares, 1982; Arvind et al., 1993; Kalpana and Sriraman, 1998) but not accordance with few other autors (Bersenyi et al., 2003; Hossain, 2005) who found vitamin E and C failed to regain TEC, TLC and $\mathrm{Hb}$ content in $\mathrm{HgCl}_{2}$ intoxicated cases.

AST and ALT values significantly $(\mathrm{p}<0.01)$ elevated at day 28 in all treated groups (Table 4) but the elevation was higher in $\mathrm{HgCl}_{2}$ intoxicated group (group B) compared to groups treated with vitamin $\mathrm{E}$ and $\mathrm{C}$ alone and in combination. The elevated value of AST in $\mathrm{HgCl}_{2}$, vitamin $\mathrm{E}$, vitamin $\mathrm{C}$ alone and in combined vitamin $\mathrm{E}$ and $\mathrm{C}$ treated groups were of $46.99 \%, 15.46 \%, 22.41 \%$ and $8.72 \%$, respectively. Where as following same treatment consecutive elevation of ALT in identical period were of $58.72 \%, 31.68 \%$, $40.82 \%$ and $18.98 \%$ respectively. 
Table 4. Effect of mercuric chloride alone and in combination with vitamin $\mathrm{E}$ and $\mathrm{C}$ supplementation on AST and ALT $\left(\mathrm{U} / \mathrm{L}\right.$ at $\left.37^{\circ} \mathrm{C}\right)$ in mice

\begin{tabular}{l|cccc}
\hline \multirow{2}{*}{ Treatment in groups } & \multicolumn{2}{|c|}{ AST (U/L) } & \multicolumn{2}{c}{ ALT (U/L) } \\
\cline { 2 - 5 } & Day-1 & Day-28 & Day-1 & Day-28 \\
\hline Control (A) & $99.59 \pm 0.24$ & $103.50 \pm 0.38$ & $46.46 \pm 0.38$ & $49.52 \pm 0.49$ \\
& & $\left(3.93 \%^{\mathrm{a}}\right)$ & & $\left(6.59 \%^{\mathrm{a}}\right)$ \\
Mercuric chloride (B) & $97.0 \pm 0.47$ & $142.43 \pm 2.96^{* *}$ & $45.18 \pm 0.34$ & $70.70 \pm 1.19^{* *}$ \\
& & $\left(46.99 \%^{\mathrm{a}}\right)$ & $\left(58.72 \%^{\mathrm{a}}\right)$ \\
Mercuric chloride + Alpha- & $98.20 \pm 0.50$ & $113.38 \pm 1.37^{* *}$ & $45.65 \pm 0.14$ & $60.11 \pm 0.44^{* *}$ \\
tocopherol (C) & $(15.46 \% \mathrm{a})$ & $\left(31.68 \%^{\mathrm{a}}\right)$ \\
Mercuric chloride + Vit C (D) & $98.2 \pm 0.63$ & $120.21 \pm 0.78^{* *}$ & $44.34 \pm 0.39$ & $62.44 \pm 0.40^{* *}$ \\
& & $(22.41 \% \mathrm{a})$ & $(40.82 \% \mathrm{a})$ \\
Mercuric chloride + Alpha- & $96.23 \pm 0.46$ & $104.63 \pm 1.58^{* *}$ & $43.35 \pm 0.35$ & $51.57 \pm 0.93$ \\
tocopherol + Vit C (E) & \multicolumn{3}{c}{$(8.72 \% \mathrm{a})$} & $(18.98 \% \mathrm{a})$ \\
\hline
\end{tabular}

Values above represent the mean \pm SE of 4 mice; ${ }^{* *}$ Significantly decreased $(\mathrm{p}<0.01)$; $(\% \mathrm{a})$ percent increased

Transaminase activities are widely used to assess the liver function. Liver is the key organ for detoxification of metal poison. ALT is a cytoplasmic enzyme which is increased in acute hepatitis, jaundice and liver cirrhosis while AST is increased in myocardial infarction, liver cancer and liver cirrhosis indicating that $\mathrm{Hg}$ has detrimental effect on liver and also on heart. It is evident that $\mathrm{HgCl}_{2}$ increased transaminase activity but administration of vitamin $\mathrm{E}$ and $\mathrm{C}$ could partially protect that increase level with a better results following combined administration. Similar results have been reported by other workers (Bersenyi et al., 2003; Moniruzzaman, 2004; Hossain, 2005), where they observed significantly increased level of AST and ALT values following $\mathrm{Hg}$ toxicosis. In contrary to the present findings, Brandao et al. (2006) observed insignificant change of AST and ALT values after $\mathrm{Hg}$ exposure for three consecutive days.

From this study it is revealed that administration of vitamin $\mathrm{E}$ and $\mathrm{C}$ alone or in combination have a protective role against harmful effects of $\mathrm{Hg}$ toxicity. However, combined effects of these vitamins were found to be much better than alone.

\section{REFERENCES}

Arvind, M., Bhargava, S. and Vineeta, J. 1993. Mercury induced some hematological changes in Channa striatus. International Journal of Occupational and Environmental Health, 2: 29-30.

ATSDR, (Agency for Toxic Substances and Disease Registery). 1989. Toxicological profile for arsenic. Agency for Toxic Substances and Disease Registery, US. Public Health Service, Atlanta, GA. TP. 88/2 ATSDR/TP-88/02.

Bersenyi, A., Fekete, S. G., Szocs, Z. and Berta, E. 2003. Effects of ingested heavy metals (Pb, Cd, $\mathrm{Hg}$ ) on hematology and serum biochemistry in rabbits. Acta Veterinaria Hungarica, 51: 297-304. 
Brandao, R., Santos, F. W., Farina, M., Zeni, G., Bohrer, D., Rocha, J. B. and Nogueira, C. W. 2006. Antioxidants and metallothionein levels in mercury-treated mice. Cell Biology and Toxicology, 22: 429-438.

Carratu, M. R., Borracci, P., Coluccia, A., Giustino, A., Renna, G., Tomasini, M. C., Raisi, E., Antonelli, T., Cuomo, V., Mazzoni, E. and Ferraro, L. 2006. Acute exposure to methylmercury at two developmental windows: focus on neurobehavioral and neurochemical effects in rat offspring. Neuroscience, 141: 1619-1629.

Chowdhury, A. R., Vachhrajani, K. D., Makhija, S. and Kashyap, S. K. 1986. Histomorphometric and biochemical changes in the testicular tissues of mice treated with mercuric chloride. Biomedica Biochimica Acta, 45: 949-956.

Clarkson, T. 1997. The toxicology of mercury. Critical Review, 34: 369-403.

Coffin, D. L. 1955. Manual of Veterinary Clinical Pathology. 3rd edn. Coinstock Publishing Associates. Inc. Ithaca New York, pp. 116-157.

Goyer, R. 1991. Toxic effects of metals. In: Casarett and Doull's Toxicology by Amdur, M. O., Doull, J. D. and Klassen, C. D. (Eds). Pergamon Press, New York, pp. 623-680.

Hirota, Y. 1986. Effect of methylmercury on the activity of glutathione peroxidase in rat liver. American Industrial Hygiene Association Journal, 47: 556-558.

Hossain, M. M. 2005. Effect of vitamin E and vitamin C supplementation on mercury intoxication in rats. M. S. Thesis, Department of Pharmacology, Bangladesh Agricultural University, Mymensingh, Bangladesh.

Houeto, P., Sandouk, P., Baud, F. J. and Levillain, P. 1994. Elemental mercury vapour toxicity: treatment and levels in plasma and urine. Human and Experimental Toxicology, 13: 848-852.

Kalpana, P. and Sriraman, P. K. 1998. Pathology of mercuric chloride toxicity in Japanese quails. Indian Journal of Animal Science, 68: 240-241.

Khan, A. Q. 1989. Epidemiology and Disease Control. 1 1st edn. World University Service Press, Dhaka University Campus, Nilkhet, Dhaka.

Kling, L. J. and Soares, J. H. 1982. The effect of mercury and vitamin E on tissue glutathione peroxidase activity and thiobarbituric acid values. Poultry Science, 61: 1762-1765.

Moniruzzaman, M. 2004. Effect of zinc and selenium supplementation on mercury intoxication in rats. M. S. Thesis, Department of Pharmacology, Bangladesh Agricultural University, Mymensingh, Bangladesh.

Naganuma, A., Ishii, Y. and Imura, N. 1984. Effect of administration sequence of mercuric chloride and sodium selenite on their fates and toxicities in mice. Ecotoxicology and Environmental Safety, 8: $572-580$.

Ngim, C. H., Foo, S. C., Boey, K. W. and Jeyaratnam, J. 1992. Chronic neurobehavioral effects of elemental mercury in dentists. British Journal of Industrial Medicine, 49: 782-790.

Uchino, M., Tanaka, Y. and Ando, Y. 1995. Neurologic features of chronic minamata disease (organic mercury poisoning) and incidence of complications with aging. The Journal of Environmental Science and Health, 30: 699-715. 